\title{
Treatment of Intracranial Aneurysms with Self-Expandable Braided Stents: A Systematic Review and Meta-Analysis
}

\author{
(D). Cagnazzo, (D) M. Cappucci, (DP.-H. Lefevre, (D) C. Dargazanli, (D) G. Gascou, (D) Rorganti, (D) V. Mazzotti, (DD. di Carlo, (DP. Perrini,
} (DD. Mantilla, (D). Riquelme, (D)A. Bonafe, and (D). Costalat

\begin{abstract}
BACKGROUND: The safety and efficacy of treatment with self-expandable braided stents (LEO and LVIS) required further investigation.

PURPOSE: Our aim was to analyze the outcomes after treatment with braided stents.

DATA SOURCES: A systematic search of 3 databases was performed for studies published from 2006 to 2017.

STUDY SELECTION: According to Preferred Reporting Items for Systematic Reviews and Meta-Analyses guidelines, we included studies reporting patients treated with LEO or LVIS stents.
\end{abstract}

DATA ANALYSIS: Random-effects meta-analysis was used to pool the following: aneurysm occlusion rate, complications, and neurologic outcomes.

DATA SYNTHESIS: Thirty-five studies evaluating 1426 patients treated with braided stents were included in this meta-analysis. Successful stent delivery and complete aneurysm occlusion were $97 \%(1041 / 1095 ; 95 \% \mathrm{Cl}, 95 \%-98 \%)\left(1^{2}=44 \%\right)$ and $88.3 \%(1097 / 1256 ; 95 \% \mathrm{Cl}, 85 \%-91 \%)$ $\left(I^{2}=72 \%\right)$, respectively. Overall, treatment-related complications were $7.4 \%(107 / 1317 ; 95 \% \mathrm{Cl}, 5 \%-9 \%)\left(I^{2}=44 \%\right)$. Ischemic/thromboembolic events $(48 / 1324=2.4 \% ; 95 \% \mathrm{Cl}, 1.5 \%-3.4 \%)\left(\mathrm{I}^{2}=27 \%\right)$ and in-stent thrombosis $(35 / 1324=1.5 \% ; 95 \% \mathrm{Cl}, 0.6 \%-1.7 \%)\left(\mathrm{I}^{2}=0 \%\right)$ were the most common complications. Treatment-related morbidity was 1.5\% (30/1324; $95 \% \mathrm{Cl}, 0.9 \%-2 \%)$ and was comparable between the LEO and LVIS groups. Complication rates between the anterior $(29 / 322=8.8 \% ; 95 \% \mathrm{Cl}, 3.4 \%-12 \%)\left(1^{2}=41 \%\right)$ versus posterior circulation $(10 / 84=10.5 \% ; 95 \% \mathrm{Cl}, 4 \%-16 \%)\left(\mathrm{I}^{2}=0 \%\right)$ and distal $(30 / 303=8 \% ; 95 \% \mathrm{Cl}, 4.5 \%-12 \%)\left(1^{2}=48 \%\right)$ versus proximal aneurysms $(14 / 153=9 \%$; $95 \% \mathrm{Cl}, 3 \%-13 \%)\left(\mathrm{I}^{2}=46 \%\right)$ were comparable $(P>.05)$.

LIMITATIONS: Limitations were selection and publication biases.

CONCLUSIONS: In this analysis, treatment with the LEO and LVIS stents was relatively safe and effective. The most common complications were periprocedural thromboembolisms and in-stent thrombosis. The rate of complications was comparable among anterior and posterior circulation aneurysms, as well as for proximal and distally located lesions.

ABBREVIATIONS: IQR = interquartile range; PRISMA = Preferred Reporting Items for Systematic Reviews and Meta-Analyses; SAC = stent-assisted coiling

$\mathrm{T}$ he development of self-expandable stents has progressively changed the treatment strategy for most intracranial aneurysms, creating a mechanical scaffold that prevents coil protrusion and promoting neoendothelization of the neck. ${ }^{1}$ Several selfexpandable stents were introduced in the past years, ${ }^{2,3}$ including

Received March 15, 2018; accepted after revision July 30

From the Neuroradiology Department (F.G., M.C., P.-H.L., C.D., G.G., C.R., A.B., V.C.) University Hospital Güi-de-Chauliac, Centre Hospitalier Universitaire de Montpellier, Montpellier, France; Department of Neurosurgery (D.d.C., P.P.), University of Pisa, Pisa, Italy; Section of Statistics (R.M., V.M.), University Hospital of Pisa, Pisa, Italy; and Neuroradiology Department (D.M.), Clinic FOSCAL, Universidad Autonoma de Bucaramanga, Andrés Bello National University, Santiago, Chili

Please address correspondence to Federico Cagnazzo, MD, Neuroradiology Department, CHU Güi De Chauliac, 80 Ave Augustin Fliche, 34000 Montpellier. France; e-mail: f.cagnazzo86@gmail.com laser-cut open-cell stents (such as the Neuroform; Stryker Neurovascular, Kalamazoo, Michigan) and laser-cut closed-cell stents (such as the Enterprise; Codman \& Shurtleff, Raynham, Massachusetts). ${ }^{2}$ The third generation of self-expandable closed stents was produced by braiding individual strands of nitinol onto a mandrel (LVIS, MicroVention, Tustin, California; and LEO, Balt Extrusion, Montmorency, France). ${ }^{4,5}$ In addition to providing mechanical support, the braided morphology gives a relatively higher pore density than the laser-cut stents, theoretically improving the flow-diverting hemodynamic effect of these devic-

\footnotetext{
三Indicates article with supplemental on-line tables.

I. Indicates article with supplemental on-line photo.

http://dx.doi.org/10.3174/ajnr.A5804
} 
es. ${ }^{6-8}$ Recently, the low-profile design of the braided stents (LEO Baby and LVIS Jr) allowed delivery through a 0.0165-inch microcatheter and navigation in small vessels, with the possibility of treating distally located aneurysms. ${ }^{9,10}$ Improved understanding of treatment-related outcomes of braided stents can help practitioners in the selection of lesions amenable to being effectively treated with these devices. Our meta-analysis examined occlusion rates and procedure-related complications after treatment with braided stents, focusing on the influence of aneurysm features, location, and treatment characteristics on the studied outcomes.

\section{MATERIALS AND METHODS Literature Search}

A comprehensive literature search of PubMed, Ovid MEDLINE, and Ovid EMBASE was conducted for studies published from January 2006 to February 2018. The Preferred Reporting Items for Systematic Reviews and Meta-Analyses (PRISMA) guidelines ${ }^{11}$ were followed. The key words and the detailed search strategy are reported in On-line Table 1. The inclusion criteria were the following: studies reporting series of intracranial aneurysms treated with LEO and LVIS stents. Exclusion criteria were the following: 1) review articles, 2) studies published in languages other than English, 3) in vitro studies, and 4) animal studies. In cases of overlapping patient populations, only the series with the largest number of patients or the most detailed data was included. Two independent readers screened articles in their entirety to determine eligibility for inclusion. A third author solved discrepancies.

\section{Data Collection}

From each study, we extracted the following: 1) treatment-related complications, 2) occlusion rate, and 3) clinical outcome. Occlusion and complication rates were analyzed on the basis of the influence of the following parameters: 1) unruptured-versusacutely ruptured aneurysms, 2) distal-versus-proximal location, 3) anterior-versus-posterior circulation, 4) first treatment versus retreatment, 5) stent alone versus stent-assisted coiling (SAC), and 6) single-versus-multiple stents. A subgroup analysis was performed for aneurysms treated with small low-profile braided stents (LEO Baby and LVIS Jr). Distal location was considered for lesions arising distal to the circle of Willis or located in small vessels: A2-3 segments, middle cerebral artery, posterior cerebral artery, posterior inferior cerebellar artery, anterior inferior cerebellar artery, and superior cerebellar artery. The occlusion rate was defined on the basis of the Raymond-Roy classification. Accordingly, we used the following terms: complete occlusion (class I), residual neck or near complete occlusion (class II), and incomplete occlusion or residual aneurysm (class III). ${ }^{12}$ Treatment-related complications were divided into 2 groups: periprocedural/early events (within 30 days after treatment) and delayed events (after 30 days). Finally, good outcome was defined as a modified Rankin Scale score of $0-2$ or a Glasgow Outcome Score of 4-5, or it was assumed if the study used terms such as "no morbidity," "good recovery," or "no symptoms."

\section{Outcomes}

The primary objectives of this meta-analysis were to define the safety (treatment-related complications, neurologic outcomes, mortality rate) and the efficacy (aneurysm occlusion rate) of the treatment of intracranial aneurysms with self-expanding braided stents (LEO and LVIS). The secondary objectives were to define the influence of aneurysm location, aneurysm characteristics, and factors related to the treatment on the analyzed outcomes.

\section{Quality Scoring}

A modified version of the Newcastle-Ottawa Scale ${ }^{13}$ was used for quality assessment of the included studies. The details are reported in On-line Tables 2 and 3. The quality assessment was performed by 2 authors independently, and a third author solved discrepancies.

\section{Statistical Analysis}

We estimated, from each cohort, the cumulative prevalence (percentage) and 95\% confidence interval for each outcome. Percentages were calculated with a random-effects meta-analysis. Heterogeneity across studies was evaluated using the $\mathrm{I}^{2}$ statistic: An $\mathrm{I}^{2}$ value of $>50 \%$ suggests substantial heterogeneity. To compare the percentages and to calculate the $P$ values, we used the $Z$-test for 2 proportions. Meta-regression was not used in this study. Statistical analysis was performed using OpenMeta[Analyst] (http://www.cebm. brown.edu/openmeta/).

\section{RESULTS}

\section{Literature Review}

Studies included in our meta-analysis are summarized in On-line Table 4. The search flow diagram is shown in the On-line Figure.

A total of 35 studies and 1426 patients with 1518 intracranial aneurysms treated with LEO or LVIS stents were included in our review.

\section{Quality of Studies}

Overall, 14 studies (40\%) were rated "high quality" (On-line Tables 2 and 3). Three articles were prospective multicentric series, 5 studies were obtained from a prospectively maintained data base, 3 studies were retrospective multicentric, and 24 articles were single-center retrospective.

\section{Patient Population}

Overall, 510 aneurysms (33.5\%) were treated with LEO stents and 948 aneurysms $(62.5 \%)$ were treated with LVIS devices. One study with 60 aneurysms (4\%) reported patients treated with LEO and LVIS stents (On-line Table 5). The mean age of patients (54.5 years; range, 7-79 years) and the male/female ratio (0.47) were comparable between the 2 groups. Overall, $83 \%$ (1172/1410; $95 \%$ CI, $81 \%-84 \%$ ) of aneurysms were located in the anterior circulation. The mean aneurysm size was $7.2 \mathrm{~mm}$ (range, 2-65 $\mathrm{mm}$ ). Most aneurysms were found incidentally (572/954 $=60 \%$; $95 \%$ CI, 56\%-63\%). The mean radiologic and clinical follow-up was 10.4 months (interquartile range [IQR], 6-12 months; median, 6.5 months) and 12 months (IQR, 6-13 months; median, 8 months), respectively.

AJNR Am J Neuroradiol 39:2064-69 Nov 2018 www.ajnr.org 


\section{Angiographic Outcomes}

Overall, the devices were successfully delivered in 97\% (1041/ 1095; 95\% CI, 95\%-98\%) ( $\mathrm{I}^{2}=44 \%$ ) of cases (On-line Table 6). The technical success rate was 97.5\% (379/396; 95\% CI, 95\%98\%) $\left(\mathrm{I}^{2}=42 \%\right)$ and 97\% (662/699; 95\% CI, 95\%-99\%) $\left(\mathrm{I}^{2}=\right.$ $58 \%$ ) for LEO and LVIS stents, respectively. During a mean angiographic follow-up of 10.4 months (median, 6.5 months; IQR, 6-12 months), the overall rate of complete/near-complete occlusion was 88.3\% (1097/1256; 95\% CI, 85\%-91\%) ( $\left.\mathrm{I}^{2}=72 \%\right)$ : Complete/near-complete occlusion was achieved in $88.6 \%(410 /$ 463; 95\% CI, 83\%-93\%) ( $\left.\mathrm{I}^{2}=69 \%\right)$ and 87.8\% (687/793; 95\% CI, 83\%-92\%) (I $\left.{ }^{2}=74 \%\right)$ of aneurysms treated with LEO and LVIS stents, respectively.

\section{Treatment-Related Complications}

The overall complication rate was 7.4\% (107/1317; 95\% CI, 5\%$9 \%)\left(\mathrm{I}^{2}=44 \%\right)$. Complications were higher among LEO stents $(46 / 391=10.5 \% ; 95 \% \mathrm{CI}, 7 \%-13 \%)\left(\mathrm{I}^{2}=0 \%\right)$ compared with LVIS stents $\left(54 / 867=5.3 \%\right.$; 95\% CI, 3\%-7\%) $\left(\mathrm{I}^{2}=34 \%\right)(P=$ $.001)$. The overall rate of permanent complications was $1.5 \%$ (30/ 1324; 95\% CI, 0.9\%-2\%) ( $\left.\mathrm{I}^{2}=0 \%\right)$. Permanent complications were $2.7 \%(17 / 398 ; 95 \% \mathrm{CI}, 1 \%-4 \%)\left(\mathrm{I}^{2}=3 \%\right)$ and $1.3 \%(12 /$ 867; 95\% CI, 0.6\%-2.2\%) ( $\left.\mathrm{I}^{2}=0 \%\right)$ after LEO and LVIS stent treatment, respectively $(P=.002)$.

Most complications were periprocedural or early events (85/ $1324=5 \%$; 95\% CI, 3\%-6\%) $\left(\mathrm{I}^{2}=36 \%\right)$, whereas delayed complications were $1 \%(27 / 1324 ; 95 \% \mathrm{CI}, 0.5 \%-1.6 \%)\left(\mathrm{I}^{2}=0 \%\right)$. Both periprocedural and delayed complications were higher in the LEO group (On-line Table 6). Overall, the most common complications were ischemic/thromboembolic events (48/ $1324=2.4 \%$; 95\% CI, 1.5\%-3.4\%) $\left(\mathrm{I}^{2}=27 \%\right)$, followed by instent thrombosis $\left(35 / 1324=1.5 \%\right.$; 95\% CI, 0.6\%-1.7\%) $\left(\mathrm{I}^{2}=\right.$ $0 \%)$. After treatment with LEO stents, there was a higher incidence of ischemic/thromboembolic events (21/398 $=3.6 \%$; $95 \%$ CI, $1.8 \%-5 \%$ versus $24 / 867=1.6 \%$; 95\% CI, $0.6 \%-1.5 \%)(P=$ $.03)$ and in-stent thrombosis $(19 / 398=3.2 \%$; 95\% CI, $1.5 \%-5 \%$ versus $15 / 867=0.8 \%$; 95\% CI, $0.2 \%-1.5 \%)(P=.003)$. Ischemic complications were related to the following events: thromboembolism (44/48 = 91\%; 95\% CI, 79\%-97\%), perforating injury due to stent coverage of lenticulostriate arteries $(1 / 48=2 \%$; $95 \% \mathrm{CI}$, $0.1 \%-10 \%)$, and platelet aggregation in the side branches covered with the stent $(3 / 48=6.5 \% ; 95 \% \mathrm{CI}, 1.5 \%-17 \%)$. The rate of aneurysm perforation/vessel dissection during treatment and the rate of intraparenchymal hemorrhage (unrelated to aneurysm rupture) were $1.3 \%(22 / 1324 ; 95 \% \mathrm{CI}, 0.7 \%-1.8 \%)\left(\mathrm{I}^{2}=0 \%\right)$ and $0.5 \%(1 / 1324 ; 95 \% \mathrm{CI}, 0.1 \%-1.1 \%)\left(\mathrm{I}^{2}=0 \%\right)$, respectively, without differences between the 2 groups. The incidence of aneurysm rupture after treatment was $0.7 \%$ (3/1324; 95\% CI, 0.3\%$1.1 \%)\left(\mathrm{I}^{2}=0 \%\right)$. Treatment-related mortality was $0.7 \%(3 / 1357$; 95\% CI, $0.3 \%-1.2 \%)\left(\mathrm{I}^{2}=0 \%\right)$, whereas the rate of good neurologic outcome was $98 \%$ (770/78; 95\% CI, 97\%-99\%) ( $\left.\mathrm{I}^{2}=0 \%\right)$.

\section{Factors Related to Aneurysm Occlusion}

Overall, the occlusion rate of distally located aneurysms and more proximal lesions was $89.5 \%$ (237/272; 95\% CI, 86\%-93\%) (I ${ }^{2}=$ $0 \%)$ and $77 \%(90 / 124 ; 95 \% \mathrm{CI}, 66 \%-87 \%)\left(\mathrm{I}^{2}=57 \%\right)$, respectively $(P=.001)$ (On-line Table 7$)$. Complete/near-complete oc- clusion in the anterior circulation $(149 / 174=88.5 \%$; $95 \%$ CI, $82 \%-94 \%)\left(\mathrm{I}^{2}=34 \%\right)$ was higher compared with the posterior circulation $\left(26 / 37=70 \%\right.$; 95\% CI, 53\%-86\%) $\left(\mathrm{I}^{2}=47 \%\right)(P=$ $.003)$. Occlusion after retreatment with braided stents of aneurysms recanalized after previous treatments was lower $(31 / 42=$ $75 \%$; 95\% CI, 54\%-94\%) (I $\left.\mathrm{I}^{2}=57 \%\right)$ compared with the occlusion rate of the first treatment $(179 / 203=88.9 \%$; $95 \%$ CI, $83 \%-$ $94 \%)\left(\mathrm{I}^{2}=23 \%\right)(P=.01)$. Differences in occlusion rates were not statistically significant in relation to single-versus-multiple overlapping devices. SAC was more effective compared with treatment with a stent alone: a complete/near-complete occlusion rate of $90 \%(807 / 898 ; 95 \% \mathrm{CI}, 86 \%-93 \%)\left(\mathrm{I}^{2}=67 \%\right)$ versus $63 \%$ $\left(19 / 26 ; 95 \%\right.$ CI, 40\%-90\%) ( $\left.\mathrm{I}^{2}=48 \%\right)$, respectively $(P=.0001)$. In the stent-alone group, 58\% (15 aneurysms) and 42\% (11 aneurysms) of patients were treated with single and double stents, respectively.

\section{Factors Related to Complications after Treatment}

The complication rate was higher for ruptured aneurysms treated in the acute phase $(12 / 75=14.5 \% ; 95 \% \mathrm{CI}, 7 \%-21 \%)\left(\mathrm{I}^{2}=0 \%\right)$ compared with unruptured lesions $(54 / 675=6.6 \%$; $95 \% \mathrm{CI}$, $4.8 \%-4 \%)\left(\mathrm{I}^{2}=0 \%\right)(P=.01)$. There was no statistically significant difference in complication rates among distal-versus-proximal locations and anterior-versus-posterior circulation. Similarly, treatment-related complications were comparable among first treatment versus retreatment, SAC versus stent alone, and single-versus-multiple stents.

\section{Angiographic Outcomes and Treatment-Related Complications for Low-Profile Braided Stents (LEO Baby and LVIS Jr)}

Low-profile braided stents were successfully delivered in $96 \%$ (601/638; 95\% CI, 94\%-98\%) ( $\left.\mathrm{I}^{2}=41 \%\right)$ of cases, without differences between the LEO Baby and LVIS Jr (On-line Table 8). Overall, $61 \%(318 / 521 ; 95 \%$ CI, 56\%-65\%) of low-profile braided stents were deployed in small and distal vessels, whereas $39 \%(203 / 521 ; 95 \%$ CI, 34\%-43\%) were used to treat proximally located aneurysms. In addition, LEO Baby and LVIS Jr were mostly used for the treatment of anterior circulation aneurysms $(296 / 399=74 \% ; 95 \%$ CI, 69\%-78\%) compared with posterior circulation lesions $(103 / 399=26 \%$; 95\% CI, 21\%-30\%). Overall, complete/near-complete occlusion was $88.6 \%$ (507/580; 95\% CI, $84 \%-92 \%)\left(\mathrm{I}^{2}=63 \%\right)$ and was higher with the LEO Baby $(135 /$ $143=96.3 \% ; 95 \%$ CI, 93\%-99\%) $\left(\mathrm{I}^{2}=0 \%\right)$ compared with LVIS $\operatorname{Jr}\left(372 / 437=86 \%\right.$; 95\% CI, 80\%-91\%) $\left(\mathrm{I}^{2}=65 \%\right)(P=.005)$. The overall complication rate was $7.2 \%(54 / 636 ; 95 \%$ CI, 5\%$9 \%)\left(\mathrm{I}^{2}=0 \%\right)$ with $1.9 \%(13 / 636 ; 95 \% \mathrm{CI}, 0.9 \%-2.9 \%)\left(\mathrm{I}^{2}=\right.$ $0 \%)$ permanent events. LEO Baby devices were associated with a $3.7 \%\left(4 / 148\right.$; 95\% CI, 0.7\%-6\%) ( $\left.\mathrm{I}^{2}=0 \%\right)$ permanent complication rate, whereas LVIS Jr stents had 1.6\% (9/488; 95\% CI, $0.5 \%-2.8 \%)\left(\mathrm{I}^{2}=0 \%\right)(P=.7)$. The most common complications were ischemic/thromboembolic $(22 / 636=1.8 \% ; 95 \% \mathrm{CI}$, $0.7 \%-2.8 \%)\left(\mathrm{I}^{2}=0 \%\right)$ and in-stent thrombosis $(21 / 636=1.6 \%$; 95\% CI, 0.6\%-2.6\%) ( $\left.\mathrm{I}^{2}=4 \%\right)$. In-stent thrombosis was higher among LEO Baby $\left(9 / 148=5 \%\right.$; 95\% CI, 2\%-8\%) $\left(\mathrm{I}^{2}=0 \%\right)$ compared with LVIS Jr (12/488 = 1.1\%; 95\% CI, 0.2\%-2\%) (I ${ }^{2}=$ $0 \%)$. Treatment-related mortality and good neurologic outcome 
were $0.8 \%(1 / 636 ; 95 \% \mathrm{CI}, 0.4 \%-1.5 \%)\left(\mathrm{I}^{2}=0 \%\right)$ and $98.3 \%$ (406/415; 95\% CI, 96\%-99\%) (I $\left.{ }^{2}=0 \%\right)$, respectively.

\section{Study Heterogeneity}

Analysis of the angiographic outcomes and treatment-related complications showed high heterogeneity in $10 \%$ of the reported results ( 4 of 39 studied outcomes) (On-line Table 6). The analysis of the factors related to complications and occlusion (On-line Table 5) showed high heterogeneity in $18 \%$ of the studied events (4 of 22 reported outcomes). The rate of high heterogeneity among complications and angiographic outcomes after LEO Baby and LVIS Jr (On-line Table 7) was 9\% (3 of 33 reported results).

\section{DISCUSSION}

With the advent of the SAC technique, most complex, wide-neck intracranial aneurysms can be efficiently treated endovascularly. ${ }^{14}$ Compared with other intracranial stents that are laser-cut from nitinol hypotubes, LEO and LVIS stents are braided from a single nitinol wire with a closed-cell design. ${ }^{6,8}$ Because of the increased use of these devices, understanding the safety and efficacy of treatment with braided stents is important in the management of lesions amenable to SAC treatment.

\section{Angiographic Outcomes}

In combining aneurysmal occlusion rates from 35 series, our analysis provides more representative data on angiographic outcomes than any single study. We demonstrated high rates of complete/ near-complete occlusion for both LEO (88.6\%; 95\%, CI 83\%93\%) and LVIS devices (87.8\%; 95\% CI, 83\%-92\%). Meta-analysis of aneurysms treated with SAC using different devices showed $61 \%$ long-term occlusion. ${ }^{15}$ The high rates of occlusion after treatment with braided stents can be related to the smaller cell size, higher metal coverage and flow-diversion effect than other conventional self-expandable stents. ${ }^{6,8,16}$ Computational fluid dynamics studies showed that LVIS stents allowed more flow reduction than laser-cut devices, and double LVIS stents resulted in a better flow-diverting effect than the Pipeline Embolization Device (PED; Covidien, Irvine, California). ${ }^{8}$ Aydin et al, ${ }^{16}$ investigating the flow-diversion effect of low-profile braided stents used as stent monotherapy, reported $75 \%$ complete occlusion during follow-up. In the subgroup of aneurysms treated with double stents, the authors showed a slightly higher rate of complete occlusion $(82 \%)$. In our study, braided stents used as stent monotherapy allowed a $63 \%(95 \% \mathrm{CI}, 40 \%-90 \%)$ complete occlusion rate, which was significantly lower compared with the treatment with stent plus coiling (90\%; 95\% CI, 86\%-93\%) $(P=.0001)$. Most interesting, lesions treated with SAC with single or multiple stents had comparable rates of occlusion, showing that in most cases, a single stent is enough to achieve complete aneurysm occlusion, avoiding the ischemic complications related to the higher metal density in the vessel.

\section{Treatment-Related Complications}

In general, treatment-related complications and morbidity after SAC are $12 \%$ and $5 \%$, respectively. ${ }^{17,18}$ In our analysis, treatment with braided stents was relatively safe, with overall rates of complications and morbidity of 7.4\% (95\% CI, 5\%-9\%) and 1.5\%
(95\% CI, 0.9\%-2\%), respectively. This is in accordance with a recent prospective, multicentric study of LVIS devices that reported approximately $5 \%$ treatment-related morbidity. ${ }^{19}$ Most interesting, the overall complication rate was higher after treatment with LEO $(10.5 \%$; 95\% CI, 7\%-13\%) compared with LVIS stents (5.3\%; 95\% CI, 3\%-7\%). The higher rate of complications was related to higher ischemic/thromboembolic events (3.6\%; 95\% CI, $1.5 \%-5 \%$ versus $1.6 \%$; 95\% CI, $0.6 \%-$ $2.5 \%)$ and in-stent thrombosis $(3.2 \%$; $95 \%$ CI, $1.5 \%-5 \%$ versus $0.8 \%$; $95 \% \mathrm{CI}, 0.2 \%-1.5 \%)$. After we investigated the literature, the rate of in-stent thrombosis after treatment with laser-cut stents was $1 \%,{ }^{2}$ which is lower compared with the overall rate of both braided stents and low-profile braided stents $(1.5 \%$ and $1.6 \%$, respectively). Similar to that in flowdiverter stents, the higher incidence of acute occlusion of braided stents compared with laser-cut devices can be explained, at least in part, by the higher mesh density and more condensed pores of these devices. However, in our meta-analysis, LVIS and LVIS Jr had a low incidence of acute in-stent occlusion $(0.8 \%$ and $1.1 \%$, respectively), which appears quite comparable with that in the laser-cut stents.

Knowledge of the safety of braided stents in relation to the location and characteristics of the aneurysms has important therapeutic implications. Most interesting, we found comparable rates of complications between proximal (ICA and circle of Willis) and distal aneurysms beyond the circle of Willis or in small vessels. The rate of complications for distal aneurysms treated with flow-diverter stents ranges between $15 \%$ and $20 \% .^{20,21}$ Feng et $\mathrm{l}^{22}$ reported 5\% complications after SAC of MCA aneurysms with LVIS Jr stents. Similarly, Aydin et al ${ }^{16}$ reported a high occlusion rate and a low incidence $(5 \%)$ of complications after flow-diversion treatment of aneurysms at or distal to the circle of Willis, with low-profile braided stents used as stent monotherapy.

Although the occlusion rate was lower in the posterior circulation (70\%; 95\% CI, 53\%-86\% versus $88.5 \%$; $95 \%$ CI, $82 \%-$ $94 \%)$, treatment-related complications were comparable between anterior $(8.8 \%$; $95 \% \mathrm{CI}, 3.4 \%-12 \%)$ and posterior circulation aneurysms (10.5; 95\% CI, 4\%-16\%) $(P=.7)$. Similarly, Johnson et $\mathrm{al}^{23}$ in a large series of 486 aneurysms treated with Neuroform and Enterprise stents, reported comparable rates of complications among anterior (11.5\%) and posterior circulation lesions $(12.7 \%)$. Contrariwise, flow diversion in the posterior circulation is associated with not negligible rates of ischemic complications related to perforators infarcts. In the International Retrospective Study of Pipeline Embolization Device, the rates of morbidity and mortality after flow diversion treatment were higher among posterior circulation (16.5\%) compared with anterior circulation lesions $(5 \%-9 \%) .^{24}$

Finally, our subgroup analysis of $>600$ aneurysms treated with low-profile braided stents (LEO Baby and LVIS Jr) demonstrated comparable results in terms of the safety (complication rate $=$ 7.2\%; 95\% CI, 5\%-9\%) and efficacy (complete/near-complete occlusion $=96.3 \%$; 95\% CI, 93\%-99\%) of these devices usually used in smaller and distal vessels because of the possibility of being delivered through a 0.0165 -inch microcatheter. 


\section{Strength and Limitations}

Our study has limitations. Most series are retrospective studies and single-institution experiences. Details of the antiplatelet therapy were infrequently specified. The smaller number of cases in some subgroup analyses may not provide sufficient power to demonstrate a statistically significant difference among the studied outcomes. However, although retrospective data are low in quality, our meta-analysis is the best available evidence to guide the treatment management of aneurysms with braided stents.

\section{CONCLUSIONS}

In our study, treatment with the LEO and LVIS stents was relatively safe and effective. Most of the complications were related to periprocedural thromboembolic events and in-stent thrombosis. We found comparable rates of treatment-related complications among anterior-versus-posterior circulation aneurysms and for proximal-versus-distally located lesions. These findings can guide practitioners in the treatment, management, and selection of aneurysms amenable to treatment with braided stents.

\section{ACKNOWLEDGMENTS}

We thank Beth De Felici for the English revision.

Disclosures: Federico Cagnazzo_UNRELATED: Employment: University of Florence.* Pierre-Henri Lefevre-UNRELATED: Payment for Development of Educational Presentations: Medtronic, Stryker.* Paolo Perrini-UNRELATED: Employment: Azienda Ospedaliero Universitaria Pisana, Comments: I work as Associate Professor of Neurosurgery, University of Pisa, Italy, and as a consultant neurosurgeon at Azienda OspedalieroUniversitaria Pisana, Pisa, Italy. Carlos Riquelme_UNRELATED: Employment: Hopital Güi de Chauliac, service de neuroradiology. * Vincent Costalat—UNRELATED: Consultancy: Stryker, Medtronic*; Grants/Grants Pending: Stryker, Medtronic*; Payment for Development of Educational Presentations: Medtronic, Stryker, Balt Extrusion. *Money paid to the Institution.

\section{REFERENCES}

1. Wanke I, Forsting M. Stents for intracranial wide-necked aneurysms: more than mechanical protection. Neuroradiology 2008; 50:991-98 CrossRef Medline

2. King B, Vaziri S, Singla A, et al. Clinical and angiographic outcomes after stent-assisted coiling of cerebral aneurysms with Enterprise and Neuroform stents: a comparative analysis of the literature. J Neurointerv Surg 2015;7:905-09 CrossRef Medline

3. Brinjikji W, Murad MH, Lanzino G, et al. Endovascular treatment of intracranial aneurysms with flow diverters: a meta-analysis. Stroke 2013;44:442-47 CrossRef Medline

4. Fiorella D, Arthur A, Boulos A, et al. Final results of the US humanitarian device exemption study of the low-profile visualized intraluminal support (LVIS) device. J Neurointerv Surg 2016;8:894-97 CrossRef Medline

5. Lubicz B, Kadou A, Morais R, et al. Leo stent for endovascular treatment of intracranial aneurysms: very long-term results in 50 patients with 52 aneurysms and literature review. Neuroradiology 2017;59:271-76 CrossRef Medline

6. Cho SH, Jo WI, Jo YE, et al. Bench-top comparison of physical properties of 4 commercially-available self-expanding intracranial stents. Neurointervention 2017;12:31-39 CrossRef Medline

7. Gross BA, Frerichs KU. Stent usage in the treatment of intracranial aneurysms: past, present and future. J Neurol Neurosurg Psychiatry 2013;84:244-53 CrossRef Medline

8. Wang C, Tian Z, Liu J, et al. Flow diverter effect of LVIS stent on cerebral aneurysm hemodynamics: a comparison with Enterprise stents and the Pipeline device. J Transl Med 2016;14:199 CrossRef Medline

9. Aydin K, Arat A, Sencer S, et al. Stent-assisted coiling of wide-neck intracranial aneurysms using low-profile LEO Baby stents: initial and midterm results. AJNR Am J Neuroradiol 2015;36:1934-41 CrossRef Medline

10. Möhlenbruch M, Herweh C, Behrens L, et al. The LVIS Jr. microstent to assist coil embolization of wide-neck intracranial aneurysms: clinical study to assess safety and efficacy. Neuroradiology 2014;56: 389-95 CrossRef Medline

11. Moher D, Liberati A, Tetzlaff J, et al. Preferred Reporting Items for Systematic Reviews and Meta-Analyses: the PRISMA statement. Int J Surg 2010;8:336-41 CrossRef Medline

12. Roy D, Milot G, Raymond J. Endovascular treatment of unruptured aneurysms. Stroke 2001;32:1998-2004 CrossRef Medline

13. Wells G, Shea B, O'Connell D, et al. The Newcastle-Ottawa Scale (NOS) for assessing the quality of nonradomized studies in metaanalyses. Ottawa: Ottawa Hospital Research Institute; 2011. http:// www.evidencebasedpublichealth.de/download/Newcastle_Ottowa_ Scale_Pope_Bruce.pdf. Accessed February 5, 2018

14. Chalouhi N, Jabbour P, Singhal S, et al. Stent-assisted coiling of intracranial aneurysms: predictors of complications, recanalization, and outcome in 508 cases. Stroke 2013;44:1348-53 CrossRef Medline

15. Shapiro M, Becske T, Sahlein D, et al. Stent-supported aneurysm coiling: a literature survey of treatment and follow-up. AJNR Am J Neuroradiol 2012;33:159-63 CrossRef Medline

16. Aydin K, Barburoglu M, Sencer S, et al. Flow diversion with lowprofile braided stents for the treatment of very small or uncoilable intracranial aneurysms at or distal to the circle of Willis. AJNR AmJ Neuroradiol 2017;38:2131-37 CrossRef Medline

17. Feng MT, Wen WL, Feng ZZ, et al. Endovascular embolization of intracranial aneurysms: to use stent (s) or not? Systematic review and meta-analysis. World Neurosurg 2016;93:271-78 CrossRef Medline

18. Phan K, Huo YR, Jia F, et al. Meta-analysis of stent-assisted coiling versus coiling-only for the treatment of intracranial aneurysms. J Clin Neurosci 2016;31:15-22 CrossRef Medline

19. Iosif C, Piotin M, Saleme S, et al; TRAIL Investigators. Safety and effectiveness of the Low Profile Visualized Intraluminal Support (LVIS and LVIS Jr) devices in the endovascular treatment of intracranial aneurysms: results of the TRAIL multicenter observational study. J Neurointerv Surg 2018;10:675-81 CrossRef Medline

20. Gawlitza M, Januel AC, Tall P, et al. Flow diversion treatment of complex bifurcation aneurysms beyond the circle of Willis: a single-center series with special emphasis on covered cortical branches and perforating arteries. J Neurointerv Surg 2016;8:481-87 CrossRef Medline

21. Cagnazzo F, Mantilla D, Lefevre PH, et al. Treatment of middle cerebral artery aneurysms with flow-diverter stents: a systematic review and meta-analysis. AJNR Am J Neuroradiol 2017;38:2289-94 CrossRef Medline

22. Feng Z, Li Q, Zhao R, et al. Endovascular treatment of middle cerebral artery aneurysm with the LVIS Junior stent. J Stroke Cerebrovasc Dis 2015;24:1357-62 CrossRef Medline

23. Johnson AK, Munich SA, Tan LA, et al. Complication analysis in nitinol stent-assisted embolization of 486 intracranial aneurysms. J Neurosurg 2015;123:453-59 CrossRef Medline

24. Kallmes DF, Hanel R, Lopes D, et al. International retrospective study of the Pipeline embolization device: a multicenter aneurysm treatment study. AJNR Am J Neuroradiol 2015;36:108-15 CrossRef Medline

25. Kis B, Weber W, Berlit P, et al. Elective treatment of saccular and broad-necked intracranial aneurysms using a closed-cell nitinol stent (Leo). Neurosurgery 2006;58:443-50; discussion 443-50 CrossRef Medline

26. Juszkat R, Nowak S, Smól S, et al. Leo stent for endovascular treatment of broad-necked and fusiform intracranial aneurysms. Interv Neuroradiol 2007;13:255-69 CrossRef Medline

27. Yang P, Liu J, Huang Q, et al. Endovascular treatment of wide-neck middle cerebral artery aneurysms with stents: a review of 16 cases. AJNR Am J Neuroradiol 2010;31:940-46 CrossRef Medline 
28. Luo J, Lv X, Jiang C, et al. Preliminary use of the Leo stent in the endovascular treatment of wide-necked cerebral aneurysms. World Neurosurg 2010;73:379-84 CrossRef Medline

29. Lv X, Li Y, Jiang C, et al. Potential advantages and limitations of the Leo stent in endovascular treatment of complex cerebral aneurysms. Eur J Radiol 2011;79:317-22 CrossRef Medline

30. Akmangit I, Aydin K, Sencer S, et al. Dual stenting using low-profile LEO baby stents for the endovascular management of challenging intracranial aneurysms. AJNR Am J Neuroradiol 2015;36:323-29 CrossRef Medline

31. Machi P, Costalat V, Lobotesis K, et al. LEO Baby stent use following balloon-assisted coiling: single- and dual-stent technique-immediate and midterm results of 29 consecutive patients. AJNR Am J Neuroradiol 2015;36:2096-103 CrossRef Medline

32. Negrotto M, Crosa R, Casagrande W. Assisted coiling using LEO Baby or LVIS Jr stents: report of six cases. Interv Neuroradiol 2015; 21:566-74 CrossRef Medline

33. Chau Y, Mondot L, Sachet M, et al. Modification of cerebral vascular anatomy induced by Leo stent placement depending on the site of stenting: a series of 102 cases. Interv Neuroradiol 2016;22:666-73 CrossRef Medline

34. Voigt P, Schob S, Jantschke R, et al. Stent-assisted coiling of ruptured and incidental aneurysms of the intracranial circulation using moderately flow-redirecting, braided LEO stents: initial experience in 39 patients. Front Neurol 2017;8:602 CrossRef Medline

35. Sedat J, Chau Y, Gaudart J, et al. Stent-assisted coiling of intracranial aneurysms using LEO stents: long-term follow-up in 153 patients. Neuroradiology 2018;60:211-19 CrossRef Medline

36. Poncyljusz W, Biliński P, Safranow K, et al. The LVIS/LVIS Jr. stents in the treatment of wide-neck intracranial aneurysms: multicentre registry. J Neurointerv Surg 2015;7:524-29 CrossRef Medline

37. Cho YD, Sohn CH, Kang HS, et al. Coil embolization of intracranial saccular aneurysms using the Low-profile Visualized Intraluminal Support (LVIS) device. Neuroradiology 2014;56:543-51 CrossRef Medline

38. Behme D, Weber A, Kowoll A, et al. Low-profile Visualized Intraluminal Support device (LVIS Jr) as a novel tool in the treatment of wide-necked intracranial aneurysms: initial experience in 32 cases. J Neurointerv Surg 2015;7:281-85 CrossRef Medline

39. Feng Z, Zhang L, Li Q, et al. Endovascular treatment of wide-neck anterior communicating artery aneurysms using the LVIS Junior stent. J Clin Neurosci 2015;22:1288-91 CrossRef Medline

40. Samaniego EA, Abdo G, Hanel RA, et al. Endovascular treatment of PICA aneurysms with a Low-profile Visualized Intraluminal Sup- port (LVIS Jr) device. J Neurointerv Surg 2016;8:1030-33 CrossRef Medline

41. Alghamdi F, Mine B, Morais R, et al. Stent-assisted coiling of intracranial aneurysms located on small vessels: midterm results with the LVIS Junior stent in $\mathbf{4 0}$ patients with $\mathbf{4 3}$ aneurysms. Neuroradiology 2016;58:665-71 CrossRef Medline

42. Du EH, Shankar JJ. LVIS Jr 'shelf' technique: an alternative to Y stent-assisted aneurysm coiling. J Neurointerv Surg 2016;8:1256-59 CrossRef Medline

43. Shankar JJ, Quateen A, Weill A, et al. Canadian Registry of LVIS Jr for Treatment of Intracranial Aneurysms (CaRLA). J Neurointerv Surg 2017;9:849-53 CrossRef Medline

44. Grossberg JA, Hanel RA, Dabus G, et al. Treatment of wide-necked aneurysms with the Low-profile Visualized Intraluminal Support (LVIS Jr) device: a multicenter experience. J Neurointerv Surg 2017; 9:1098-102 CrossRef Medline

45. Lim JW, Lee J, Cho YD. Progressive occlusion of small saccular aneurysms incompletely occluded after stent-assisted coil embolization: analysis of related factors and long-term outcomes. Clin Neuroradiol 2017 Aug 8. [Epub ahead of print] CrossRef Medline

46. Wang CC, Fang YB, Zhang P, et al. Reconstructive endovascular treatment of vertebral artery dissecting aneurysms with the Lowprofile Visualized Intraluminal Support (LVIS) device. PLoS One 2017;12:e0180079 CrossRef Medline

47. Feng X, Qian Z, Liu P, et al. Comparison of recanalization and in-stent stenosis between the Low-profile Visualized Intraluminal Support stent and Enterprise stent-assisted coiling for 254 intracranial aneurysms. World Neurosurg 2018;109:e99-104 CrossRef Medline

48. Santillan A, Boddu S, Schwarz J, et al. LVIS Jr. stent for treatment of intracranial aneurysms with parent vessel diameter of $2.5 \mathrm{~mm}$ or less. Interv Neuroradiol 2018;24:246-53 CrossRef Medline

49. Yoo DH, Cho YD, Moon J, et al. Long-term outcomes of LowProfile Visualized Intraluminal Support device usage in stentassisted coiling of intracranial aneurysm. J Clin Neurosci 2018; 50:287-91 CrossRef Medline

50. Gao BL, Li TX, Li L, et al. Tiny cerebral aneurysms can be treated safely and effectively with Low-Profile Visualized Intraluminal Support stent-assisted coiling or coiling alone. World Neurosurg 2018;113:e426-30 CrossRef Medline

51. Cheung NK, Chiu AH, Cheung A, et al. Long term follow-up of bifurcation aneurysms treated with braided stent assisted coiling and complex T- and Y- stent constructs. J Neurointerv Surg 2018;10: 560-65 CrossRef Medline 